\title{
Borrelia garinii in Seabird Ticks (Ixodes uriae), Atlantic Coast, North America
}

\author{
Robert P. Smith, Jr, ${ }^{*}$ Sabir Bin Muzaffar, $†$ Jennifer Lavers, $†$ Eleanor H. Lacombe, ${ }^{*}$ Bruce K. Cahill,* \\ Charles B. Lubelczyk, ${ }^{*}$ Allen Kinsler, ${ }^{*}$ Amy J. Mathers, ${ }^{*}$ and Peter W. Rand*
}

Borrelia garinii is the most neurotropic of the genospecies of $B$. burgdorferi sensu lato that cause Lyme disease in Europe, where it is transmitted to avian and mammalian reservoir hosts and to humans by Ixodes ricinus. $B$. garinii is also maintained in an enzootic cycle in seabirds by $I$. uriae, a tick found at high latitudes in both the Northern and Southern Hemispheres. To determine whether B. garinii is present in seabird ticks on the Atlantic Coast of North America, we examined 261 l. uriae ticks by polyclonal antiborrelial fluorescent antibody. Ten of 61 ticks from Gull Island, Newfoundland, were positive for borreliae by this screen. Amplicons of DNA obtained by PCR that targeted the $B$. garinii rrs-rrla intergenic spacer were sequenced and matched to GenBank sequences for $B$. garinii. The potential for introduction of this agent into the North American Lyme disease enzootic is unknown.

Tn Europe, Lyme disease is caused by 3 genospecies of Borrelia burgdorferi (i.e., B. afzelii, B. garinii, $B$. burgdorferi sensu stricto), while in North America only $B$. burgdorferi sensu stricto, the genospecies present in $I$. scapularis ticks, has been implicated in human disease. $B$. garinii, the most neurotropic of these 3 genospecies, causes most neurologic Lyme disease in Europe, including cases of meningopolyneuritis and, rarely, encephalomyelitis (1-3). The presence of multiple pathogenic genospecies that cause Lyme disease in Europe complicates serodiagnostic testing (4).

In Eurasia, B. garinii is transmitted to avian and rodent hosts and to humans by $I$. ricinus, the sheep or forest tick,

*Maine Medical Center Research Institute, South Portland, Maine, USA; and †Memorial University of Newfoundland, Saint John's, Newfoundland, Canada and I. persulcatus, the taiga tick (5-9). I. uriae, the seabird tick, also maintains this agent in a "silent" enzootic cycle in seabirds at their nesting sites over a wide but discontinuous area (10-13). Although these 2 enzootic cycles are generally geographically and ecologically separate, interchange of $B$. garinii strains may occur at sites where both vectors coexist (14). The risk for seabird-associated strain types of $B$. garinii to cause Lyme disease, however, is not known (15).

Although B. garinii is present in seabird ticks in a nearly circumpolar distribution in both the Northern and Southern Hemispheres $(12,13)$, including Alaska, the presence of $B$. garinii in $I$. uriae ticks at sites on the North Atlantic Coast has not previously been documented. We sought to determine whether $B$. garinii is present in ticks obtained from colonial seabird nesting sites on the Atlantic Coast of North America.

\section{Methods}

Seabird researchers working at several sites on the Atlantic Coast in the United States and Canada (Figure 1) submitted I. uriae ticks to our laboratory for analysis (16). Ticks were identified to species, stage, and degree of engorgement (17). A subset of ticks was dissected, and midguts were screened for spirochetes by fluorescent microscopy by using a polyclonal antiborrelial antibody (18).

DNA was extracted from Borrelia-positive ticks by using the Qiagen DNeasy Tissue Kit (Qiagen, Valencia, CA, USA). DNA amplification was performed in a designated room with genus-specific primers that include the partial sequence of rrs-rrla intergenic spacer region as described by Bunikis et al. (19) with use of negative con- 

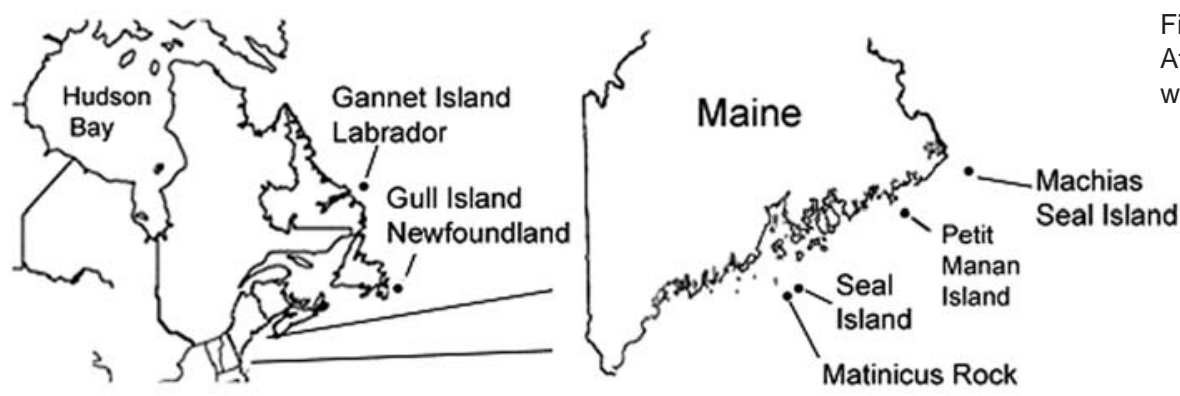

Figure 1. Locations in Maine (USA) and Atlantic Canada where Ixodes uriae ticks were collected.

trols. Amplification products were viewed on a $1 \%$ agarose gel containing $0.5 \mu \mathrm{g} / \mathrm{mL}$ ethidium bromide. At a second laboratory, ticks positive by fluorescent antibody screen were prepared as above for DNA extraction, and PCR was performed by using primers directed at the $16 \mathrm{~S}$ ribosomal DNA. Sequences of amplicons obtained at both laboratories were confirmed to be $B$. garinii by comparison with known sequences in the GenBank database.

\section{Results}

I. uriae ticks submitted from 6 seabird colony sites and several hosts in the United States and Canada were processed (Table). Through 2005, $880 \mathrm{I}$. uriae ticks recovered primarily from Atlantic puffin chicks or their nests, were submitted from Maine sites, and another 383 were submitted from sites on the Atlantic Coast of Canada. Over 200 ticks from Maine sites and 61 ticks from Canadian sites off the coast of Newfoundland and Labrador were screened for borreliae by fluorescent microscopy.

Spirochetes were detected only in ticks from Gull Island, Newfoundland $\left(47^{\circ} 15^{\prime} \mathrm{N}, 52^{\circ} 46^{\prime} \mathrm{W}\right)$, where 9 of 22 adults and 1 of 39 nymphal ticks were positive. DNA was extracted from 2 of these ticks, and PCR showed a 1,900-base amplicon of the rrs-rrls intergenic spacer region that matched with $B$. garinii on comparison with GenBank sequences. Two additional ticks were examined in the laboratory of Sam Telford (Tufts University School of Veterinary Medicine, Grafton, MA, USA) by means of
PCR targeting of $16 \mathrm{~S}$ ribosomal DNA and again confirmed a match for B. garinii (GenBank bankit no. 800902 DG463373). Figure 2 shows the sequence from one of the ticks shown in an alignment with sequences from $B$. burgdorferi strain B31 and a representative B. garinii sample from GenBank.

\section{Discussion}

The finding of B. garinii in I. uriae ticks from Gull Island, Newfoundland, adds to the known distribution of this agent and increases the likelihood that this agent is present in other colonial seabird nesting sites on the Atlantic Coast of North America, as is the case in Europe. The recent emergence of $I$. scapularis in coastal Maine and some Maritime Canadian sites $(20,21)$ brings these 2 enzootic cycles of different genospecies of $B$. burgdorferi into proximate areas, although their ecologic settings differ. The public health importance of this finding depends on the probability of the introduction of $B$. garinii into emergent $I$. scapularis-vectored B. burgdorferi s.s. cycles and its potential maintenance in this cycle. The public health effects also depend on the pathogenic potential for human disease caused by seabird-associated strains of $B$. garinii (15).

The remote geographic and, at some sites, isolated topographic location of colonial seabird colonies provide significant barriers to the introduction of $B$. garinii into other vector ticks and their reservoir hosts. I. scapularis is

\begin{tabular}{|c|c|c|c|c|c|c|c|c|}
\hline \multirow[b]{2}{*}{ Site } & \multicolumn{5}{|c|}{ Host species } & \multirow[b]{2}{*}{$\begin{array}{c}\text { On } \\
\text { humans }\end{array}$} & \multirow[b]{2}{*}{$\begin{array}{l}\text { Flag/drag } \\
\text { sampling }\end{array}$} & \multirow[b]{2}{*}{$\begin{array}{l}\text { Soil/litter } \\
\text { sample }\end{array}$} \\
\hline & $\begin{array}{c}\text { Atlantic } \\
\text { puffin } \\
\text { (Fratercula } \\
\text { arctica) } \\
\end{array}$ & $\begin{array}{c}\text { Murre (Uria } \\
\text { aalge)/Razorbill } \\
\text { (Alca torda) }\end{array}$ & $\begin{array}{c}\text { Black guillemot } \\
\text { (Cepphus } \\
\text { grille) }\end{array}$ & $\begin{array}{l}\text { Herring gull } \\
\text { (Larus } \\
\text { argentatus) }\end{array}$ & $\begin{array}{c}\text { Common } \\
\text { eider } \\
\text { (Somateria } \\
\text { mollissima) }\end{array}$ & & & \\
\hline $\begin{array}{l}\text { Machias Seal } \\
\text { Island }^{*}\end{array}$ & 218 & & & & & 5 & 52 & \\
\hline Matinicus Rock* & 258 & 23 & 25 & & & 210 & & \\
\hline Petit Manan Island* & 56 & & 12 & & & & & \\
\hline Seal Island* & 46 & & & & & & & \\
\hline Gannet Island $\dagger$ & 111 & 88 & & & 8 & 72 & 31 & \\
\hline Gull Island $\ddagger$ & 22 & & & 22 & & 5 & 76 & 200 \\
\hline
\end{tabular}




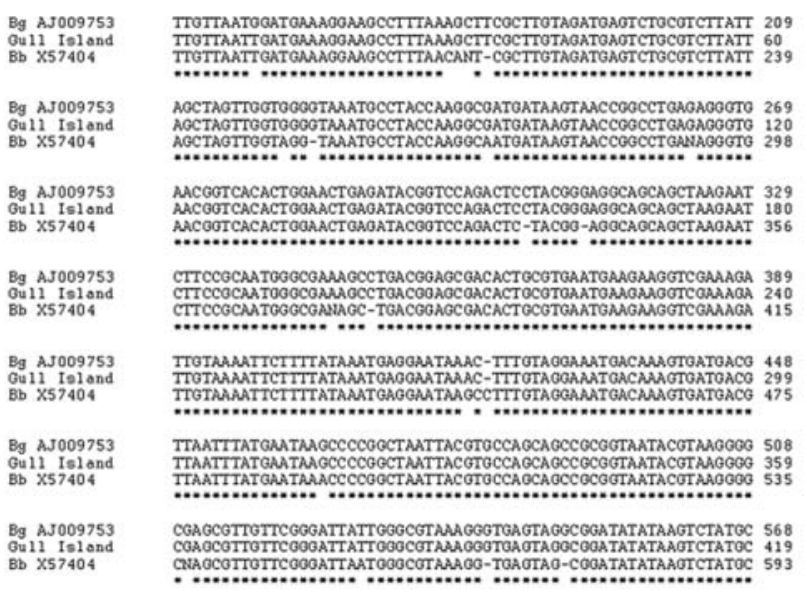

Figure 2. Alignments of 16S RNA sequences from GenBank: Bg AJ009753, Borrelia garinii; Bb X57404, B. burgdorferi strain B31, Gull Island, Newfoundland, Canada.

dispersed to remote coastal islands of the North American Atlantic Coast during bird migration $(22,23)$, but its establishment at these sites requires the presence of deer (24-26). With rare exception, deer are absent from sites with large seabird colonies, which are usually limited to offshore islands. Dispersal of infected I. uriae to proximate coastal areas by seabird hosts is unlikely because most species of seabirds parasitized by I. uriae are highly philopatric and forage at sea. One exception might be gulls, which may move between coastal and island sites. Passerine birds, which may forage near seabird colonies, provide another potential mechanism for dispersal of $B$. garinii, either through movement of infected $I$. uriae ticks or by serving as reservoir hosts of this agent. However, the frequency of parasitism of passerine birds by I. uriae ticks is unknown.

If $B$. garinii was introduced into I. scapularis ticks, its maintenance in this cycle would depend on the vector competence of $I$. scapularis for B. garinii, the reservoir competence of available hosts, and perhaps the population genetics and strain diversity of $B$. garinii $(14,27)$. Although I. scapularis is vector-competent for transmission of $B$. garinii to rodents, its efficiency of transmission appears lower than for B. burgdorferi s.s. (28). In addition, the vector competence of $I$. scapularis for seabird-associated strains of $B$. garinii has not been tested. The presence of similar ribotypes of $B$. garinii in I. ricinus ticks on a European island suggests that interchange of different $B$. garinii strains in different ecologic cycles may occur (14).

To determine the public health importance of B. garinii in seabird colonies along the North Atlantic coast, additional studies on the issues of dispersal, vector competence, and reservoir host competence are needed. All strain types of B. garinii may not be pathogenic for humans, and future studies should also address the potential for seabirdassociated strains to cause disease.

\section{Acknowledgments}

We thank Anthony Diamond of the University of New Brunswick, Linda Welch of the Maine Coastal Islands National Wildlife Refuge, and Stephen Kress of the National Audubon Society, and their staffs, for the collection of I. uriae from Machias Seal Island, Petit Manan Island, Seal Island, and Matinicus Rock during the past 12 years. We are also indebted to Jonas Bunikis, Sam R. Telford III, Heidi K. Goethert, Barbara Conley, and Cal Vary for their assistance in confirming the genetic identity of B. garinii.

Dr Smith is an infectious disease physician and codirector of the Vector-borne Disease Laboratory at the Maine Medical Center Research Institute. His research interests include the ecology of Lyme disease emergence and the strain diversity of B. burgdorferi.

\section{References}

1. Steere AC, Coburn J, Glickstein L. The emergence of Lyme disease. J Clin Invest. 2004;113:1093-101.

2. Oschmann P, Dorndoff W, Hornig C, Schafer C, Wellensiek HJ, Pflughaupt KW. Stages and syndromes of neuroborreliosis. J Neurol. 1998;245:262-72.

3. Halpern JJ. Nervous system Lyme disease. Vector Borne Zoonotic Dis. 2002;2:241-7.

4. Hauser U, Lehnert G, Lobentamzer R, Wilske B. Interpretation criteria for standardized Western blots for three European species of Borrelia burgdorferi sensu lato. J Clin Microbiol. 1997;35:1433-44.

5. Gern L, Humair P-F. Ecology of Borrelia burgdorferi sensu lato in Europe. In: Gray JS, Kahl O, Lane RS, Stanek G, editors. Lyme borreliosis: biology, epidemiology, and control. New York: CABI Publishing; 2002. p. 149-74.

6. Nakao M, Miyamoto K, Fukunaga M. Lyme disease spirochetes in Japan: enzootic transmission cycles in birds, rodents, and Ixodes persulcatus ticks. J Infect Dis. 1994;170:878-82.

7. Kurtenbach K, Peacey M, Rijpkema SGT, Hoodless AN, Nuttall PA, Randolph SE. Differential transmission of the genospecies of Borrelia burgdorferi sensu lato by game birds and small rodents in England. Appl Environ Microbiol. 1998;64:1169-73.

8. Humair P-F, Postic D, Wallich R, Gern L. An avian reservoir (Turdus merula) of the Lyme borreliosis spirochetes. Zentrabl. Bakteriol. 1998;287:521-38.

9. Richter D, Endepols S, Ohlenbusch A, Eiffert H, Spielman A, Matuschka FR. Genospecies diversity of Lyme disease spirochetes in rodent reservoirs. Emerg Infect Dis. 1999;5:291-6.

10. Olsen B, Jaenson TGT, Noppa L, Bunikis J, Bergstrom S. A Lyme borreliosis cycle in seabirds and Ixodes uriae ticks. Nature. 1993;362:340-2.

11. Olsen B, Duffy DC, Jaenson TGT, Gylfe A. J. Bonnedahl J, Bergstrom S. Transhemispheric exchange of Lyme disease spirochetes by seabirds. J Clin Microbiol. 1995;33:3270-4.

12. Gylfe A, Olsen B, Strasevicius D, Ras NM, Weihe P, Noppa L, et al. Isolation of Lyme disease borrelia from puffins (Fratercula arctica) and seabird ticks (Ixodes uriae) on the Faeroe Islands. J Clin Microbiol. 1999;37:890-6. 
13. Gylfe A, Yabuki M, Drotz M, Bergstrom S, Fukunaga M, Olsen B. Phylogenetic relationships of Ixodes uriae (Acari: Ixodidae) and their significance to transequatorial dispersal of Borrelia garinii. Hereditas. 2001;134:195-9.

14. Bunikis J, Olsen B, Fingerle V, Bonnedahl J, Wilske B, Bergstrom S. Molecular polymorphism of the Lyme disease agent Borrelia garinii in Northern Europe is influenced by a novel enzootic Borrelia focus in the North Atlantic. J Clin Microbiol. 1996;34:364-8.

15. Baranton G, Seinost G, Theodore G, Postic D, Dykhuizen D. Distinct levels of genetic diversity of Borrelia burgdorferi are associated with different aspects of pathogenicity. Res Microbiol. 2001;152:149-56.

16. Keirans JE, Lacombe EH. First records of Amblyomma americanum, Ixodes (Ixodes) dentatus, and Ixodes (Ceratixodes) uriae (Acari: Ixodidae) from Maine. J Parasitol. 1998;84:629-31.

17. Cooley RA, Kohls GM. The genus Ixodes in North America. Nat. Inst Health Bull (Edinb). 1945;184:223-8.

18. Donahue JG, Piesman J, Spielman A. Reservoir competence of whitefooted mice for Lyme disease spirochetes. Am J Trop Med Hyg. 1987;36:92-6.

19. Bunikis J, Garpmo U, Tsao J, Berglund J, Fish D, Barbour AG. Sequence typing reveals extensive strain diversity of the Lyme borreliosis agents Borrelia burgdorferi in North America and Borrelia afzelii in Europe. Microbiology. 2004;150:1741-55.

20. Bell CR, Specht HB, Coombs BA. The search for Ixodes dammini and Borrelia burgdorferi in Nova Scotia. Can J Infect Dis. 1992;3:224-30.

21. Scott JD, Fernando K, Banerjee SN, Durden LA, Byrne SK, Banerjee $\mathrm{M}$, et al. Birds disperse ixodid (Acari: Ixodidae) and Borrelia burgdorferi-infected ticks in Canada. J Med Entomol. 2001;38:493-500.

22. Smith RP Jr, Rand PW, Lacombe EH, Morris SR, Holmes DW, Caporale DA. Role of bird migration in the long-distance dispersal of Ixodes dammini, the vector of Lyme disease. J Infect Dis. 1996;174:221-4.
23. Morshed MG, Scott JD, Banerjee SN, Banerjee M, Fitzgerald T, Fernando K, et al. First isolation of Lyme disease spirochete, Borrelia burgdorferi, from black-legged tick, Ixodes scapularis, removed from a bird in Nova Scotia, Canada. Can Com Dis Rep. 1999;25:153-5.

24. Wilson ML, Telford SR III, Piesman J, Spielman A. Reduced abundance of immature Ixodes dammini (Acari: Ixodidae) following elimination of deer. J Med Entomol. 1988;25:224-8.

25. Rand PW, Lubelczyk C, Holman MS, Lacombe EH, Smith RP Jr. Abundance of Ixodes scapularis (Acari:Ixodidae) after the complete removal of deer from an isolated offshore island, endemic for Lyme disease. J Med Entomol. 2004;41:779-84.

26. Rand PW, Lubelczyk C, Lavigne GR, Elias S, Holman MS, Lacombe $\mathrm{EH}$, et al. Deer density and the abundance of Ixodes scapularis (Acari:Ixodidae). J Med Entomol. 2003;40:179-84.

27. Kurtenbach K, Schaefer SM, Sewall H, Peacey M, Hoodless A, Nuttal PA, et al. Differential survival of Lyme borreliosis in ticks that feed on birds. Infect Immun. 2002;70:5893-5.

28. Dolan MC, Piesman J, Mbow ML, Maupin GO, Peter O, Brossard M, et al. Vector competence of Ixodes scapularis and Ixodes ricinus (Acari: Ixodidae) for three genospecies of Borrelia burgdorferi. J Med Entomol. 1998;35:465-70.

Address for correspondence: Robert P. Smith, Vector-borne Disease Laboratory, Maine Medical Center Research Institute 75 John Roberts Rd, Suite 9B, South Portland, ME 04106, USA; email: smithr@mmc.org

The opinions expressed by authors contributing to this journal do not necessarily reflect the opinions of the Centers for Disease Control and Prevention or the institutions with which the authors are affiliated.

\section{EMERGING \\ Full text free online at www.cdc.gov/eid

The print journal is available at no charge to public health professionals

$\square$ YES, I would like to receive Emerging Infectious Diseases.

Please print your name and business address in the box and return by fax to 404-639-1954 or mail to

EID Editor

CDC/NCID/MS D61

1600 Clifton Road, NE

Atlanta, GA 30333

Moving? Please give us your new address (in the box) and print the number of your old mailing label here

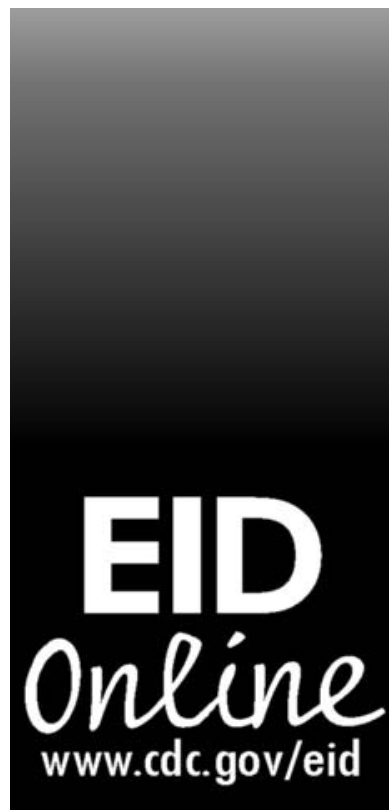

